University of Nebraska - Lincoln

DigitalCommons@University of Nebraska - Lincoln

1997

\title{
A Simulation Model Including Ovulation Rate, Potential Embryonic Viability, and Uterine Capacity to Explain Litter Size in Mice: II. Responses to Alternative Criteria of Selection
}

\author{
E. L. de A. Ribeiro \\ University of Nebraska-Lincoln \\ Merlyn K. Nielsen \\ University of Nebraska-Lincoln, mnielsen1@unl.edu \\ Kreg A. Leymaster \\ University of Nebraska-Lincoln, kleymaster2@unl.edu \\ Gary Bennett \\ University of Nebraska-Lincoln, gary.bennett@ars.usda.gov
}

Follow this and additional works at: https://digitalcommons.unl.edu/animalscifacpub

Part of the Animal Sciences Commons

de A. Ribeiro, E. L.; Nielsen, Merlyn K.; Leymaster, Kreg A.; and Bennett, Gary, "A Simulation Model Including Ovulation Rate, Potential Embryonic Viability, and Uterine Capacity to Explain Litter Size in Mice: II. Responses to Alternative Criteria of Selection" (1997). Faculty Papers and Publications in Animal Science. 501.

https://digitalcommons.unl.edu/animalscifacpub/501

This Article is brought to you for free and open access by the Animal Science Department at DigitalCommons@University of Nebraska - Lincoln. It has been accepted for inclusion in Faculty Papers and Publications in Animal Science by an authorized administrator of DigitalCommons@University of Nebraska - Lincoln. 


\title{
A Simulation Model Including Ovulation Rate, Potential Embryonic Viability, and Uterine Capacity to Explain Litter Size in Mice: II. Responses to Alternative Criteria of Selection ${ }^{1}$
}

\author{
E. L. de A. Ribeiro*,2, M. K. Nielsen*,3, K. A. Leymastert, and G. L. Bennett \\ *Department of Animal Science, University of Nebraska-Lincoln 68583-0908 and \\ ${ }^{\dagger}$ Roman L. Hruska U. S. Meat Animal Research Center, \\ ARS, USDA, Clay Center, NE 68933-0166
}

\begin{abstract}
Direct selection for litter size was compared with selection for ovulation rate, ova success, or uterine capacity and for indexes of ovulation rate with ova success or uterine capacity. Selection was simulated for 10 generations in a mouse population based on a model integrating ovulation rate, potential embryonic viability, and uterine capacity. Two indexes including ovulation rate (OR) and ova success (OS) were I $=.291 \times \mathrm{OR}+2.19 \times \mathrm{OS}$ and I $=.165 \times$ OR $+.736 \times$ OS. Heritabilities for ovulation rate and ova success, assumed in the simulation and to derive the indexes, were .25 and .06 , respectively. Both indexes resulted in the same response in litter size, $12.9 \%$ greater than response to direct selection for litter size. Two indexes including OR and uterine
\end{abstract}

capacity (TUC = true total uterine capacity; UC = uterine capacity measured as number born for a female with right ovary excised) were I $=.881 \times \mathrm{OR}+$ $.223 \times$ TUC and $\mathrm{I}=.876 \times \mathrm{OR}+.568 \times \mathrm{UC}$. Heritabilities assumed for uterine capacity were .09 (TUC) and .065 (U C). The first index assumed true parameters for uterine capacity (TUC) and resulted in a response in litter size that was $23.9 \%$ greater than direct selection. The second index was calculated using parameters estimated under a unilateralovariectomy model and resulted in response that was $14.7 \%$ greater than direct selection. Selection for OR, TUC, UC, or OS resulted in responses that were 4.5, $48.5,38.7$, or $74.8 \%$, respectively, less than that from direct selection for litter size.

Key Words: Mice, Selection, Litter Size, Simulation, Uterus, Ovulation Rate

J. Anim. Sci. 1997. 75:652-656

\section{Introduction}

Genetic improvement of litter size at birth is possible through direct selection for number born or for its components. When selection is for individual components, such as ovulation rate, response of the selected trait is positive, but correlated response in litter size has been less than the response to direct selection for litter size ( $L$ and and Falconer, 1969; Bradford, 1969, 1979; Gion et al., 1990; Kirby and Nielsen, 1993).

\footnotetext{
${ }^{1}$ Published as paper no. 11475, J ournal Ser. Nebraska Agric. Res. Div., Univ. of Nebraska, Lincoln 68583-0908.

${ }^{2}$ Current address: Departamento deZootecnia, Universidade Estuadual de Londrina, Londrina-PR, 86051-970, Brazil.

${ }^{3}$ To whom correspondence should be addressed: A218 Animal Science.

Received April 1, 1996.

Accepted October 16, 1996.
}

J ohnson et al. (1984) predicted that selection of pigs for an index including ovulation rate and prenatal survival would result in greater response in number born than direct selection. This was observed in results of the mouse experiment reported by Gion et al. (1990).

Bennett and Leymaster (1989) proposed a model for pigs in which litter size is due to the interaction of ovulation rate, potential embryonic viability, and uterine capacity. In simulated selection, they observed that an index of ovulation rate and uterine capacity resulted in greater responses in litter size than either an index including ovulation rate and prenatal survival or direct selection for litter size (Bennett and Leymaster, 1990b).

In a companion paper (Ribeiro et al., 1997), the model proposed by Bennett and Leymaster (1989) was modified for mice. The purpose of the present study was to use the simulation model to compare expected responses in litter size using alternative selection criteria in mice. 
Table 1. Parameters used in the estimation of selection indexes for mice

\begin{tabular}{|c|c|c|c|c|c|c|c|c|}
\hline \multirow[b]{2}{*}{ Trait } & \multirow[b]{2}{*}{ Mean } & \multirow{2}{*}{$\begin{array}{c}\text { Phenotypic } \\
\text { SD }\end{array}$} & \multirow{2}{*}{$\begin{array}{l}\text { Genetic } \\
\text { SD }\end{array}$} & \multicolumn{5}{|c|}{ Heritabilities and correlations $s^{\mathrm{a}}$} \\
\hline & & & & OR & TUC & os & OR-UT & UC-UT \\
\hline \multicolumn{9}{|l|}{ Intact female } \\
\hline Ovulation rate (OR) & 13.20 & 1.89 & .94 & .25 & .00 & -.30 & 1.00 & .18 \\
\hline Uterine capacity (TUC) & 16.30 & 6.00 & 1.80 & .00 & .09 & & .00 & .96 \\
\hline Ova success (OS) & .80 & .18 & .04 & -.15 & & .06 & & \\
\hline \multicolumn{9}{|l|}{ Altered female ${ }^{\mathrm{b}}$} \\
\hline Ovulation rate (OR-UT) & 12.53 & 1.82 & .91 & & & & .25 & .18 \\
\hline Uterine capacity (UC-UT) & 7.13 & 2.89 & .73 & & & & & .065 \\
\hline
\end{tabular}

a Heritabilities on diagonal; genetic correlations above diagonal and phenotypic correlations below diagonal.

bOR-UT (ovulation rate) and UC-UT (uterine capacity) estimated under UT (unilateral ovariectomy) model.

\section{Materials and Methods}

\section{Simulation Model}

The model including ovulation rate ( OR), potential embryonic viability, and uterine capacity to explain litter size in swine, proposed by Bennett and Leymaster (1989) and modified by Ribeiro et al. (1997) to accommodate anatomical differences in mice, was used in this work. The simulated base population from Ribeiro et al. (1997) was used as the base population to initiate selection for all criteria. Statistics for that population used in the derivation of the indexes of selection are presented in Table 1 . The programming was done with SAS (1990).

\section{Selection Criteria and Derivation of Indexes}

Two indexes including ovulation rate and ova success (OS; the proportion of ova resulting in fully formed pups) were tested. The first index $(I=.291 \times$ OR $+2.19 \times$ OS) was derived by Clutter et al. (1990), following suggestions of J ohnson et al. (1984), and was based on actual data from the base population of that experiment. This was the index used in the experiment reported by Gion et al. (1990) and Kirby and Nielsen (1993). The second index $(I=.165 \times$ OR $+.736 \times$ OS) was derived following the same procedure and was based on parameters from the simulated base population.

The derivation of these indexes followed the definition of the aggregate breeding value for litter size being the product of the breeding values for ovulation rate and ova success $\left(g_{\mathrm{LS}}=\mathrm{g}_{\mathrm{OR}} \times \mathrm{gos}_{\mathrm{O}}\right)$. In this situation, according to Smith (1967), to maximize response, the weights ( $b_{O R}$ and $b_{O S}$ ) for the selection index were obtained by solving the equations:

$$
\left[\begin{array}{l}
\mathrm{b}_{\mathrm{OR}} \\
\mathrm{b}_{\mathrm{OS}}
\end{array}\right]=\mathbf{P}^{-1} \mathbf{G}\left[\begin{array}{l}
\overline{\mathrm{X}}_{\mathrm{OS}} \\
\overline{\mathrm{X}}_{\mathrm{OR}}
\end{array}\right]
$$

where $\mathbf{P}$ and $\mathbf{G}$ are the phenotypic and genetic variance-covariance matrices, and $\bar{X}_{O S}$ and $\bar{X}_{O R}$ are the population means.
Two indexes including ovulation rate and uterine capacity, using either true uterine capacity for an intact animal (TUC), under the assumption that we could somehow measure true capacity, or uterine capacity measured on the left side (UC) under the UT model (i.e., number born for female with right ovary excised; Clutter et al. [1990]) were also tested. Derivation of these indexes followed suggestions of Bennett and Leymaster (1990b). Due to the interaction of the components in the model to describe litter size, maximum response is expected when each component has equal improvement. Thus, both indexes were calculated to have equal expected changes in total uterine capacity and potentially viable embryos. Because an ovum averaged a 92\% chance of becoming a viable embryo, the expected gain in total uterine capacity was .92 times the gain in ovulation rate.

Weights for both indexes including ovulation rate and uterine capacity were calculated by solving the equation $\mathbf{b}=\left(\mathbf{G}^{-1} \mathbf{a}\right) \quad \mathrm{p} / \mathrm{Z}$; where $\mathbf{G}$ is the genetic variance-covariance matrix, $\mathbf{a}$ is the vector of desired genetic gains, $p$ is the fraction selected, and $Z$ is the ordinate of the standardized normal curve from truncation area $\mathrm{p}$ (Pezek and Baker, 1969). The index calculated assuming true uterine capacity is measured was I $=.881 \times \mathrm{OR}+.223 \times$ TUC. The index using an indicator for uterine capacity, measured in a unilaterally ovariectomized female, was I $=.876 \times \mathrm{OR}+.568 \times$ UC. The purpose of the second index was to mimic the current method to measure uterine capacity in live animals. The first index is for the situation in which uterine capacity can somehow be measured in intact females.

Besides the four indexes described above, direct selections for litter size and for its components (ovulation rate, uterine capacity measured both ways [i.e., under the UT model and in intact animals], and ova success) were simulated. Also, assuming only additive effects, lines selected for ovulation rate and uterine capacity were crossed. Mean values of ovulation rate and uterine capacity from Generation 10 were used for the line-cross females. Crossing lines that are selected for maximum emphasis on individual 
Table 2. Simulated responses in reproductive traits after 10 generations of selection

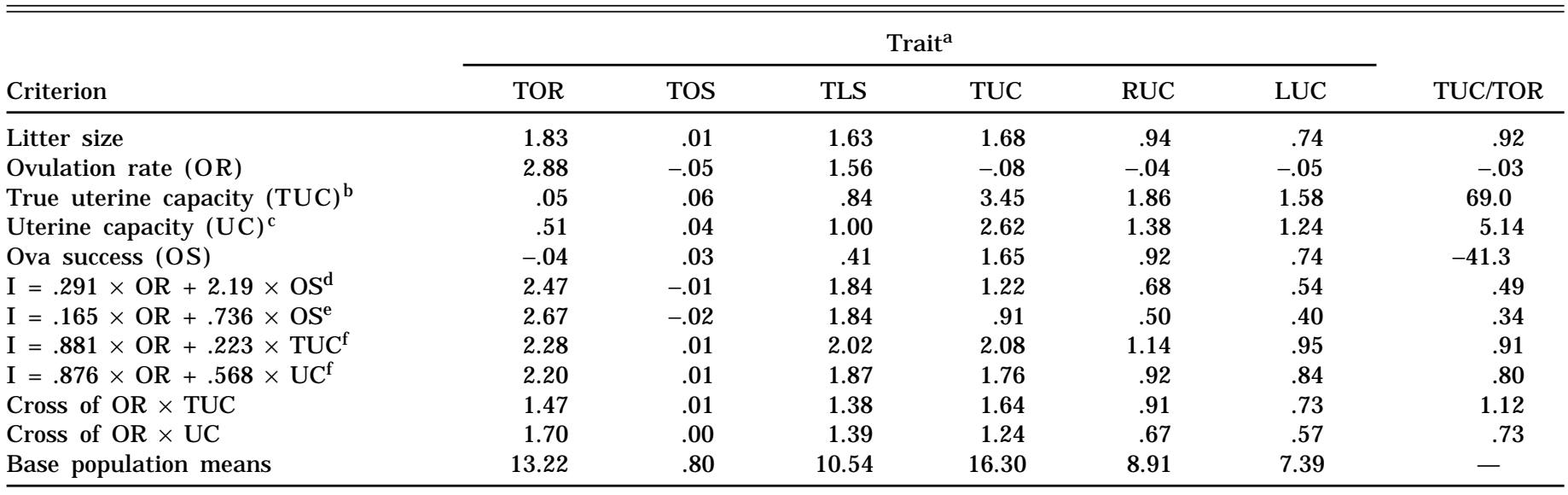

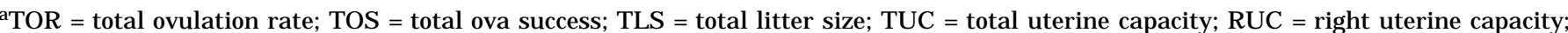

LUC = left uterine capacity.

bSelection based on true measurement of uterine capacity; intact animals.

'Selection based on the UT (unilateral ovariectomy) model; measured on left side.

Index calculated from actual data (Clutter et al., 1990).

e ndex calculated from simulated data (Ribeiro et al., 1997).

${ }^{f}$ Expected change in uterine capacity was .92 times the expected change in ovulation rate.

component traits (i.e., ovulation rate or uterine capacity) may give another application alternative for a large response due to the interaction of components. Hence, this was also evaluated.

\section{Simulated Selection}

The mating scheme was the same as used in Ribeiro et al. (1997). Briefly, every sire was mated to two females, and four daughters per litter were measured. From the total of 16,000 females measured every generation for each criterion, the 4,000 highest ranking females were selected to be dams of the next generation. Generations were discrete. Genotypic values for ovulation rate and uterine capacity of the sires were randomly sampled from distributions with mean genotype values equal to those of the 4,000 dams in the previous generation; variances of these genotypic values were as described by Ribeiro et al. (1997).

\section{Results}

Responses in ovulation rate, ova success, litter size, and uterine capacity through 10 generations of simulated selection are presented in Table 2. Selection for ovulation rate, true uterine capacity, uterine capacity under the UT model, or ova success resulted in $4.5,38.7,48.5$, and $74.8 \%$ less response, respectively, in litter size at birth than direct selection for litter size.

Direct selection for litter size changed ovulation rate and uterine capacity in the same direction, with ovulation rate at a greater rate, and slightly increased ova success. Selection for ovulation rate resulted in the greatest response in ovulation rate. Consequently, ova success decreased. Selection for uterine capacity by both methods resulted in greater response in uterine capacity and ova success, but at greater rate when using true uterine capacity rather than the UT model. Selection for uterine capacity with the UT model increased ovulation rate. Selection on ova success increased ova success through an increased uterine capacity.

The two selection indexes including ovulation rate and ova success produced a $12.9 \%$ greater response in litter size than direct selection for litter size, which was expected given the $13 \%$ higher predicted accuracy of the indexes over direct selection for litter size, but the response in litter size was realized through different pathways. The index calculated from actual data of the base generation of the mouse experiment produced a greater increase in uterine capacity than the index calculated based on parameters of the simulated base population. The increase in uterine capacity with the latter index was smaller (25.4\%), but the response in ovulation rate was greater $(8.10 \%)$ than with the first index. Both indexes produced greater response in ovulation rate than in uterine capacity. Ova success decreased -.01 and -.02 , respectively, for the first and second indexes.

The two selection indexes including ovulation rate and uterine capacity also produced greater response in litter size than direct selection for litter size. The index calculated under the UT model resulted in a response in litter size that was $14.7 \%$ greater than the response of direct selection for litter size. The index calculated with true parameters produced the greatest response in litter size among all criteria. The response in litter size for this index was $23.9 \%$ greater than the response for direct selection for litter size. In the index calculated under the UT model, uterine capacity had 
less emphasis than in the index assuming true measurement. Ova success increased slightly with both indexes. The ratios of the simulated changes in uterine capacity to ovulation rate were almost the same as those derived in the true-measurement index (.91), but smaller in the index under the UT model $(.80)$.

Response of right uterine capacity was greater than left uterine capacity for almost all criteria. The exception was the ovulation rate criterion, for which uterine capacity decreased in both sides, but slightly more on the left side. These small changes are probably due to sampling or drift.

Crossing the lines selected for ovulation rate and uterine capacity at Generation 10, assuming true parameters or uterine capacity under UT model criteria, resulted in responses in litter size that were, respectively, $15.3 \%$ and $14.7 \%$ smaller than direct selection for litter size. However, line-cross responses were 15.0 and $8.6 \%$ greater than the average responses in litter size of the lines being crossed.

\section{Discussion}

The advantage of the indexes of selection over direct selection for litter size agreed with theoretical studies that compared selection index methods with independent culling levels methods (Hazel and Lush, 1942; Bennett and Swiger, 1980). Direct selection for litter size can be considered as selection for independent culling levels of potentially viable embryos and uterine capacity (Bennett and Leymaster, 1990a).

The greater response in litter size observed with indexes including ovulation rate and uterine capacity over all other criteria agreed with findings of Bennett and Leymaster (1990b) for simulated data of pigs. They evaluated responses from two such indexes: one that took into consideration the initial ratio between uterine capacity and ovulation rate and the other that expected similar changes in ovulation rate and uterine capacity. Selection with both indexes using ovulation rate and uterine capacity resulted in greater changes in litter size than either direct selection for litter size or the index including ovulation rate and prenatal survival.

The response in litter size observed for the index including ovulation rate and uterine capacity, for which true parameters for uterine capacity were assumed, can be considered as an upper limit. However, response for the index for which parameters were estimated under the UT model can be considered as a more realistic result, because this procedure resembles our current methodology for measuring uterine capacity.

The greater response in litter size for the indexes including ovulation rate and ova success over direct selection for litter size is in accordance with what has been shown experimentally with mice by Gion et al. (1990). Indexes composed of ovulation rate and ova success, compared with indexes including ovulation rate and uterine capacity and with litter size selection, agreed with Bennett and Leymaster (1990b).

Results of selection for individual components agreed with results from Bennett and Leymaster (1990b), in which less response in litter size was observed for direct selection on each of the components compared with direct selection for litter size. The same ranking among selected lines reported by Bennett and Leymaster (1990b) was observed here, where response in litter size was greatest when selecting for ovulation rate, then for uterine capacity, and last for ova success.

Selection for ovulation rate resulted in decreased ova success, agreeing with what was expected from the negative phenotypic and genetic correlations reported by Ribeiro et al. (1997) for intact females. Although genetic and environmental correlations between ovulation rate and uterine capacity were set to zero in the simulation process, uterine capacity decreased slightly due to selection on ovulation rate; this is assumed to be due to random effects. But, in contrast, when selection was for uterine capacity in altered females, an increase in ovulation rate was observed. This can be explained by unintentional correlated selection for ovulation rate, as pointed out by Clutter et al. (1994). The UT model in mice probably does not allow all females to fully express uterine capacity, due to limited ovulation rate (Clutter et al., 1994).

Although positive changes were observed for ova success and uterine capacity, a small decrease in ovulation rate was observed due to selection on ova success. These changes resulted in a small increase in litter size. This criterion of selection was the least effective, agreeing with Bennett and Leymaster (1990b) whose simulation yielded a small decrease in litter size.

The heterosis observed for litter size (1.53 and $.93 \%)$, when crossing the ovulation rate and the uterine capacity lines, was not enough to surpass the response observed for direct selection for litter size. Because we only assumed additive effects for ovulation rate and uterine capacity, the resulting heterosis was due to the interaction of the two traits to yield litter size. If we had assumed some heterosis for the components, as did Bennett and Leymaster (1990a) for uterine capacity, the resulting response in litter size would probably be greater. Evidence of heterosis for uterine capacity in pigs was observed by Lee et al. (1994); however, for ovulation rate it is probably insignificant (J ohnson, 1981).

\section{Implications}

Selection based on an index with appropriate weights for ovulation rate and uterine capacity will improve response in litter size relative to direct selection for litter size. Another alternative is a 
selection index that includes ovulation rate and ova success, which would provide almost as much response in litter size as the ovulation rate and uterine capacity index. The success of these strategies of selection in livestock species would depend on the economical feasibility and accuracy of the estimation of the genetic parameters of these components and on our ability to measure uterine capacity.

\section{Literature Cited}

Bennett, G. L., and K. A. Leymaster. 1989. Integration of ovulation rate, potential embryonic viability and uterine capacity into a model of litter size in swine. J. Anim. Sci. 67:1230.

Bennett, G. L., and K. A. Leymaster. 1990a. Genetic implications of a simulation model of litter size in swine based on ovulation rate, potential embryonic viability and uterine capacity: I. Genetic theory. J. Anim. Sci. 68:969.

Bennett, G. L., and K. A. Leymaster. 1990b. Genetic implications of a simulation model of litter size in swine based on ovulation rate, potential embryonic viability and uterine capacity: II. Simulated selection. J. Anim. Sci. 68:980.

Bennett, G. L., and L. A. Swiger. 1980. Genetic variance and correlation after selection for two traits by index, independent culling levels and extreme selection. Genetics 94:763.

Bradford, G. E. 1969. Genetic control of ovulation rate and embryo survival in mice. I. Response to selection. Genetics 61:905.

Bradford, G. E. 1979. Genetic variation in prenatal survival and litter size. Proc. XIII Biennial Symp. on Animal Reproduction J. Anim. Sci. 49(Suppl. 2):66.

Clutter, A. C., Y.L.K. Kirby, and M. K. Nielsen. 1994. Uterine capacity and ovulation rate in mice selected 21 generations on alternative criteria to increase litter size. J . Anim. Sci. 72:577.
Clutter, A. C., M. K. Nielsen, and R. K. J ohnson. 1990. Alternative methods of selection for litter size in mice: I. Characterization of base population and development of methods. J. Anim. Sci. 68:3536.

Gion, J. M., A. C. Clutter, and M. K. Nielsen. 1990. Alternative methods of selection for litter size in mice: II. Response to thirteen generations of selection. J. Anim. Sci. 68:3543.

Hazel, L. N., and J . L. Lush. 1942. The efficiency of three methods of selection. J. Hered. 33:393.

J ohnson, R. K. 1981. Crossbreeding in swine: Experimental results. J. Anim. Sci. 52:906.

J ohnson, R. K., D. R. Zimmerman, and R. J . Kittok. 1984. Selection for components of reproduction in swine. Livest. Prod. Sci. 11: 541.

Kirby, Y. K., and M. K. Nielsen. 1993. Alternative methods of selection for litter size in mice: III. Response to 21 generations of selection. J. Anim. Sci. 71:571.

Land, R. B., and D. S. Falconer. 1969. Genetic studies of ovulation rate in the mouse. Genet. Res. (Camb.) 13:25.

Lee, G. J ., M. Ritchie, M. Thompson, A. A. Macdonald, A. Blasco, M. A. Santacreu, M. J . Argente, and C. S. Haley. 1994. A study of uterine capacity in Meishan and Large White pigs. Proc. 5th World Congr. Genet. Appl. Livest. Prod. 19:226.

Pesek, J ., and R. J . Baker. 1969. Desired improvement in relation to selection indexes. Can. J. Plant Sci. 49:803.

Ribeiro, E.L.deA., M. K. Nielsen, G. L. Bennett, and K. A. Leymaster. 1997. A simulation model including ovulation rate, potential embryonic viability, and uterine capacity to explain litter size in mice: I. Model development and implementation. J . Anim. Sci. 75:641.

SAS. 1990. SAS Language: Reference (Version 6, 1st Ed.). SAS I nst. Inc., Cary, NC.

Smith, C. 1967. A note on the improvement of a trait by selecting on its components. Anim. Prod. 9:127. 